SIMULATION OF GROUND-WATER FLOW IN THE

VICINITY OF HYDE PARK LANDFILL,

NIAGARA FALLS, NEW YORK

By Morris L. Maslia and Richard H. Johnston

U.S. GEOLOGICAL SURVEY

OPEN-FILE REPORT $82-159$ 


\section{UNITED STATES DEPARTMENT OF THE INTERIOR \\ JAMES G. WATT, Secretary}

GEOLOGICAL SURVEY

Dallas L. Peck, Director

For additional information write to:

U.S. Geological Survey

75 Spring Street, S.W., Suite 772

Atlanta, Georgia 30303 


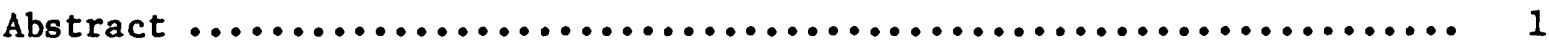

Introduction $\ldots \ldots \ldots \ldots \ldots \ldots \ldots \ldots \ldots \ldots \ldots \ldots \ldots \ldots \ldots \ldots \ldots \ldots \ldots \ldots \ldots \ldots \ldots \ldots \ldots . . . \ldots$

Hydrogeologic setting $\ldots \ldots \ldots \ldots \ldots \ldots \ldots \ldots \ldots \ldots \ldots \ldots \ldots \ldots \ldots \ldots \ldots \ldots \ldots \ldots \ldots \ldots$

Ground-water recharge and discharge $\ldots \ldots \ldots \ldots \ldots \ldots \ldots \ldots \ldots \ldots \ldots \ldots \ldots \ldots$

Saturated-unsaturated flow simulation $\ldots \ldots \ldots \ldots \ldots \ldots \ldots \ldots \ldots \ldots \ldots \ldots \ldots \ldots .7$

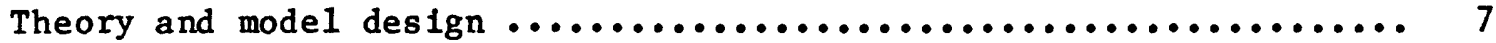

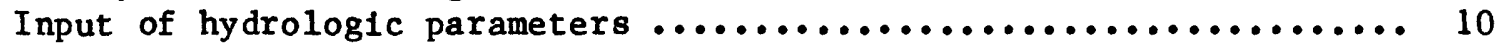

Model calibration procedure .............................. 12

Summary of ground-water flow based on simulation $\ldots \ldots \ldots \ldots \ldots \ldots \ldots \ldots . \ldots 14$

References ............................................ 19

\section{ILLUSTRATIONS}

Figure 1. Map of the Niagara Falls area showing location of the Hyde Park 1andfil1

2. Section showing hydrogeologic units, depth and location of observation wells, and average 1980 ground-water levels .......................................

3. Map showing ground-water levels in the uppermost part of the Lockport Dolomite near Hyde Park landfill .......... 8

4. Section showing finite element idealization $\ldots \ldots \ldots \ldots \ldots \ldots \ldots 11$

5. Section showing simulated water-table position and head distribution .................................

6. Section showing elemental Darcy velocity distribution ...... 16

7. Section showing estimated time of travel for ground water

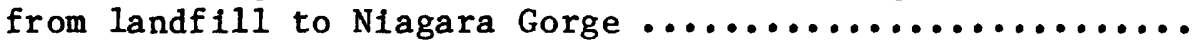

\section{TABLES}

Table 1. Water-bearing characteristics of unconsolidated deposits and bedrock in the Hyde Park area ..................... 5

2. Hydrologic parameters used in Hyde Park simulation ......... 13 


\section{GROUND-WATER VELOCITY TERMINOLOGY}

Darcy velocity as used in this report is synonymous with specific discharge or specific flux and is defined as the rate of discharge of ground water per unit area measured at right angles to the flow direction:

$$
q=\frac{Q}{A}
$$

where:

$$
\begin{aligned}
& q=\text { Darcy velocity }\left(\mathrm{LT}^{-1}\right) \\
& Q=\text { rate of flow }\left(\mathrm{L}_{\mathrm{T}}^{-1}\right) \\
& A=\text { unit area }\left(\mathrm{L}^{2}\right)
\end{aligned}
$$

Real velocity refers to the average linear velocity of the moving water and is defined as Darcy velocity divided by the effective porosity:

$$
\bar{v}=\frac{q}{n_{e}}
$$

where:

$$
\begin{aligned}
& \bar{v}=\text { real velocity }\left(\mathrm{LT}^{-1}\right) \\
& \mathrm{n}_{\mathrm{e}}=\text { effective porosity (decimal) }
\end{aligned}
$$

In terms of Darcy's law, real velocity is expressed as:

$$
\bar{v}=\frac{-k \frac{d h}{d l}}{n_{e}}
$$

where:

$$
\begin{aligned}
& \mathrm{K}=\text { hydraulic conductivity ( } \mathrm{LT}^{-1} \text { ) } \\
& \frac{\mathrm{dh}}{\mathrm{d} \mathrm{l}}=\text { hydraulic gradient (dimensionless) }
\end{aligned}
$$

In this report both real and Darcy velocities are given in feet per day. Note that in the fractured rocks, where effective porosities are very low, the real velocity is much higher than the Darcy velocity. For example in the upper unit of the Lockport Dolomite, where effective porosity is estimated to be 2 percent, a Darcy velocity of $0.02 \mathrm{ft} / \mathrm{d}$ equates to a real velocity of 1.0 $\mathrm{ft} / \mathrm{d}$. 


\section{CONVERSION FACTORS}

In this report, figures for measures are given only in inch-pound units. Factors for converting inch-pound units to metric (SI) units are shown in the following table:

Inch-pound

in (inches)

ft (feet)

$\mathrm{ft}^{3}$ (cubic feet)

mi (miles)

gal (gallons)

gal/min (gallons per minute)

$\mathrm{ft} / \mathrm{d}$ (feet per day) .305
Multiply by

25.4

.304

.02832

1.609

3.785

.0631
Metric

mm (millimeters)

$\mathrm{m}$ (meters)

$\mathrm{m}^{3}$ (cubic meters)

$\mathrm{km}$ (kilometers)

L (1iters)

L/s (liters per second)

$\mathrm{m} / \mathrm{d}$ (meters per day) $\mathrm{m}^{2} / \mathrm{d}$ (meters squared per day)

National Geodetic Vertical Datum of 1929 (NGVD of 1929): A geodetic datum derived from a general adjustment of the first-order level nets of both the United States and Canada, formerly called "mean sea level." NGVD of 1929 is referred to as sea level in this report. 


\title{
SIMULATION OF GROUND-WATER FLOW IN THE VICINITY OF HYDE PARK LANDFILL,
}

NIAGARA FALLS, NEW YORK

\author{
by Morris L. Maslia and Richard H. Johnston
}

\begin{abstract}
The Hyde Park landfill is a 15-acre chemical waste disposal site located north of Niagara Falls, New York. Underlying the site in descending order are: (1) low permeability glaclal till, (2) a moderately permeable fractured rock aquifer--the Lockport Dolomite, and (3) a low permeability unit--the Rochester Shale. The site is bounded on three sides by ground-water drains; the Niagara River Gorge, the Nlagara Power Project canal, and the power project conduits.

A finite element model was used to simulate ground-water flow along an east-west section through the Hyde Park site (from the power project conduits to the Niagara Gorge). Steady-state conditions were simulated with an average annual recharge rate of 5 inches per year. The calibrated model simulated measured water levels within 5 feet in the glacial t111 and upper unit of the Lockport Dolomite and approximated the configuration of the water table.

Based on simulation, ground-water flow near the Hyde Park site can be summarized as follows:

1. Specific discharge (Darcy velocity) ranges from about 0.01 to 0.1 foot per day in the upper unit of the Lockport Dolomite to less than 0.00001 foot per day in the Rochester Shale. Real velocities are highest in the upper unit of the Lockport, ranging from about 1.5 to 4.8 feet per day.

2. A ground-water divide exists east of the landfill, indicating that all ground water originating near or flowing beneath the landfill will flow toward and discharge in the gorge.

3. The zone of highest velocities (and presumably greatest potential for transporting chemical contaminants) includes the upper unit of the Lockport and part of the lower unit of the Lockport Dolomite between the landfill and the gorge. The time required for ground water to move from the landfill to the gorge in the Lockport Dolomite is estimated to be 5 to 7 years.
\end{abstract}

\section{INTRODUCTION}

A computer model was used to simulate ground-water flow in the vicinity of the Hyde Park landf11. The landfill is a 15-acre chemical waste disposal site just north of the city of Niagara Falls, N.Y. (fig. 1). The disposal of chemical wastes at Hyde Park landfill has been described by the Interagency 


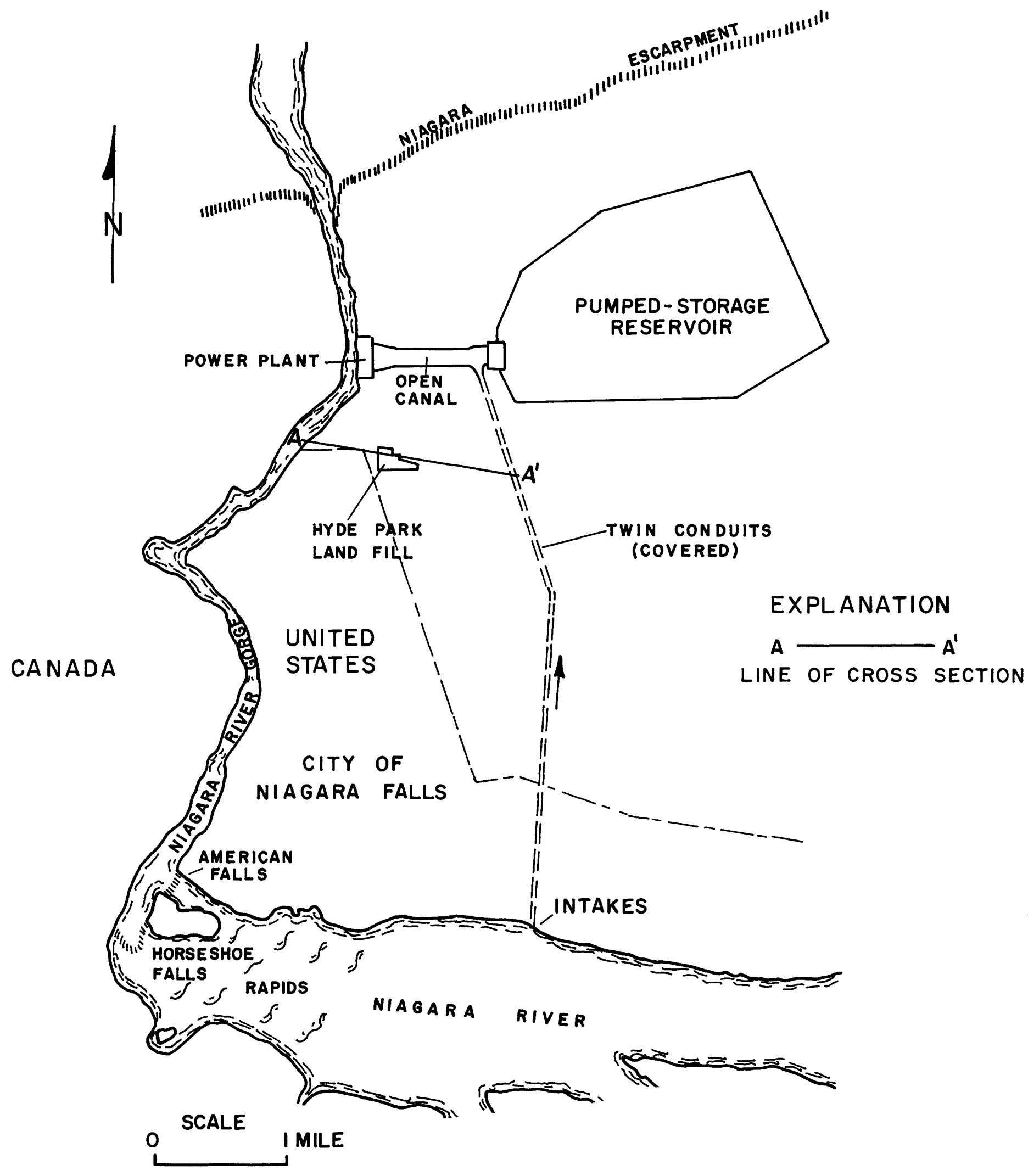

Figure 1. Niagara Falls area showing location of the Hyde Park landfill. 
Task Force on Hazardous Wastes (1979) in New York, in a report by Elder and others (1981), and in affadavits filed at the U.S. District Court, Buffalo, N.Y. (1981). In brief, the Hooker Chemical Company disposed of about 80,000 tons of chemical wastes, including mirex, lindane, trichloropheno1 (TCP), and dioxin, a highly toxic chemical by-product of TCP, in the Hyde Park landfill during 1953-75. In December 1979, the U.S. Environmental Protection Agency (EPA) and the State of New York filed suit against Hooker alleging substantial danger from the chemical wastes at the site. Negotiations were entered into between the various parties to address the problem of chemical migration from the site. In January 1981, a consent decree (proposed agreement) was entered into by all parties and filed with the U.S. District Court (western New York). During court hearings in September 1981 involving the consent decree at which the junior author testified, it became evident that a better understanding of ground-water movement in the vicinity of the Hyde Park site was needed. It is believed that the results of model simulation presented in this report will contribute toward this understanding.

The computer simulation and preparation of this report were supported by an interagency agreement between the U.S. Geological Survey and the U.S. Environmental Protection Agency (EPA). Under this agreement the Geological Survey provides assistance to EPA's Office of Waste Programs Enforcement on the assessment of geology and ground-water conditions at hazardous waste sites.

The purpose of the computer simulation was to determine the probable directions and flow velocities of ground water moving away from the landfill to nearby areas of discharge and to determine flow in the unsaturated zone. The migration of contaminants (potential or actual) away from the landfill may be partly via transport by ground water. However, this model does not address the problem of actual transport of solutes from the landfill. The transport of the potential chemical contaminants (chlorinated hydrocarbons) through the geologic media underlying this site (jointed rocks overlain by thin overburden) is highly complex. Determining the transport of chemicals involves several processes including dispersion, molecular diffusion, and chemical reactions between the various organic compounds as well as reactions with the ground water and host rock. A discussion of these processes is beyond the scope of this report.

The intent of this report is to describe--based on computer simulation-the movement of ground water in the Hyde Park area. The explanation given here is intended to show: (1) the effect of the hydraulic properties of the various geologic units on ground-water movement, (2) flow directions and velocities of ground-water movement beneath the site, (3) the probable discharge points of ground water originating in the vicinity of the landfill.

The simulation is based on the hydrogeologic framework and regional hydrology described by Johnston (1964). Site specific data on the geology, ground-water levels, and hydraulic properties of the overburden at the landfill were obtained during a program of test drilling and monitor well construction carried out by Conestoga-Rovers \& Associates $1 /$ during 1979-81.

1/Under contract to Hooker Chemical Company. 


\section{HYDROGEOLOGIC SETTING}

At the Hyde Park site a thin cover of unconsolidated deposits (glacial till and lake deposits of clay, silt, and sand) overlies the bedrock (dolomite). The hydrogeologic units are described briefly in table 1 (adapted from Johnston, 1964) and their positions and thickness are shown in a cross section through the landfill (fig. 2).

The only important aquifer is the Lockport Dolomite, a moderately permeable fractured rock aquifer. As described by Johnston (1964), ground water occurs in the Lockport Dolomite in three types of openings: (1) horizontal bedding joints, (2) vertical joints, and (3) small cavities resulting from the dissolution of gypsum. Of these, the bedding joints are the most important and transmit nearly all the water moving through the formation. The character of the three types of water-bearing openings results in two distinct types of ground-water conditions: (1) a moderately permeable zone at the top of rock, generally 10 to 15 feet thick, characterized by both vertical joints and bedding joints that have been widened by dissolution of dolomite, and by small cavities formed by dissolution of gypsum, and (2) the remainder of the formation consisting of permeable zones (composed of bedding joints) surrounded by very low permeability rock.

Abrupt changes in hydraulic head and step-like increases in well yield with depth indicate that these zones of horizontal bedding joints act as virtually separate aquifers within the Lockport Dolomite (Johnston, 1962). Thus the horizontal permeability greatly exceeds the vertical--probably by several orders of magnitude.

Pumping tests in wells tapping the Lockport Dolomite have produced a wide range of transmissivities and hydraulic conductivities. A representative value of transmissivity $(T)$ in the Niagara Falls area was obtained from an aquifer test that considered an 18,000 foot section of dewatered conduit excavation as a wel1 (Johnston, 1964, p. 34). Application of the Darcy equation to an average gradient of $0.017 \mathrm{ft} / \mathrm{ft}$ and pumping rate of about 1,000 gal/min gave a $\mathrm{T}$ of $300 \mathrm{ft}^{2} / \mathrm{d}$. The average thickness of Lockport penetrated along the conduits is about 100 feet indicating an average hydraulic conductivity of $3 \mathrm{ft} / \mathrm{d}$. In the upper 10 to 20 feet of the Lockport, the conductivity is probably higher and in the lower part it is probably lower.

The low permeability of the unconsolidated deposits is indicated by the fact that it is difficult to obtain even the modest amounts of water required for domestic use from wells in these deposits. As shown in table 1, hydraulic conductivity of these deposits is about $1 / 10$ to $1 / 1000$ of that of the Lockport Dolomite.

No data are available on the hydraulic characteristics of the Rochester Shale. Because wells are unable to produce significant water from the Rochester Shale, the hydraulic conductivity is assumed to be much lower than that of the Lockport and also probably lower than that of the unconsolidated deposits. 


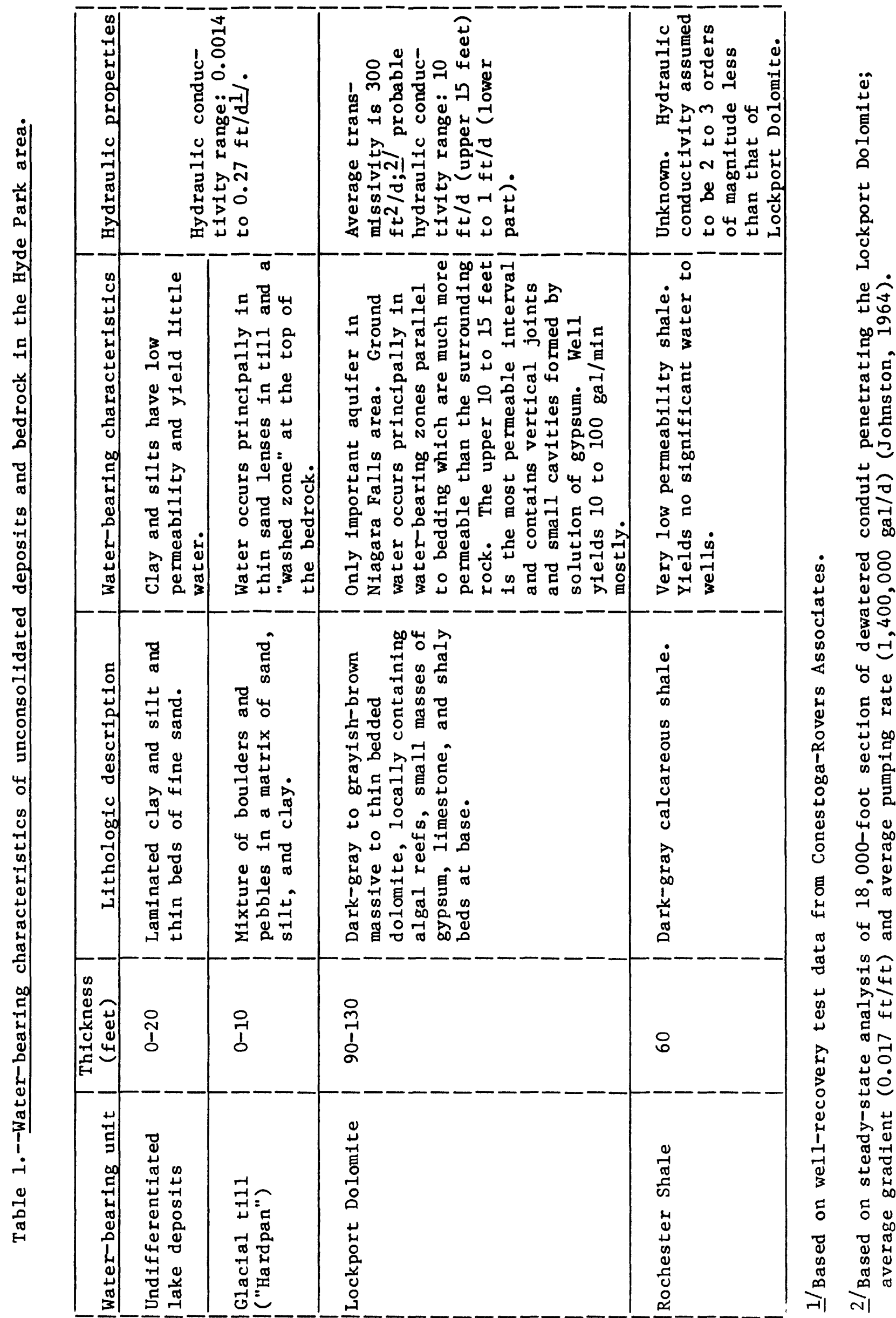




\section{GROUND-WATER RECHARGE AND DISCHARGE}

The ground-water flow system in the Hyde Park area can be described as a horizontally layered aquifer system bounded on three sides by ground-water drains. These drains ( $f i g .1$ ) are: (1) the Nlagara River Gorge (to the west) which penetrates to below the Rochester Shale, (2) the canal of the Niagara Power Project (to the north) that penetrates into the Rochester Shale, and (3) the buried conduits of the power project to the east that fully penetrate the Lockport Dolomite in the stretch near Hyde Park.

Ground water entering the area as direct infiltration of precipitation moves to one of the three lines of discharge mentioned above (Johnston, 1964, fig. 14). Infiltrating ground water initially moves through overburden of low permeability and thence into low porosity, fractured dolomite characterized by moderately high horizontal hydraulic conductivity and low vertical conductivity. The nearly impermeable Rochester Shale may effectively provide a floor to the ground-water flow system except possibly near the gorge where the shale is vertically jointed.

Except in the immediate vicinity of the Hyde Park landfill, the directions of ground-water flow are not well defined. Figure 3 shows ground-water levels and approximate contours near the landfill based on measurements in a few wells tapping the basal glacial till and uppermost part of the Lockport Dolomite (termed "interface" wells by Conestoga-Rovers Associates). The contours in figure 2 suggest a northwesterly flow of ground water (towards the gorge) in the uppermost part of the Lockport Dolomite.

The estimated head distribution in the geologic units underlying the landfill is shown in section $A-A^{\prime}$ of figure 2. The section is nearly perpendicular to the ground-water contours in figure 3 and thus approximately aligned along the principal direction of ground-water flow. The equipotentials in section $A-A^{\prime}$ suggest that ground water moves downward and towards the gorge from the landfill. This section was utilized for simulation of ground-water flow as described in the following sections.

The areal distribution of ground-water recharge in the Hyde Park area is unknown. LaSala (1967) estimated an average recharge rate of 300,000 gal/d $(6.3 \mathrm{in} / \mathrm{yr})$ for sandy areas in upstate New York with annual precipitation of $35 \mathrm{in} / \mathrm{yr}$. The annual precipitation at Niagara Falls is about $32 \mathrm{in} / \mathrm{yr}$. Thus for the purpose of simulation recharge is assumed to be slightly less than 6 inches annually. However, direct recharge to the landfill itself may be nearly zero because of the clay cap covering it.

\section{SATURATED-UNSATURATED FLOW STMULATION}

Theory and Model Design

Steady-state saturated-unsaturated flow of water movement through soil may be described by: 


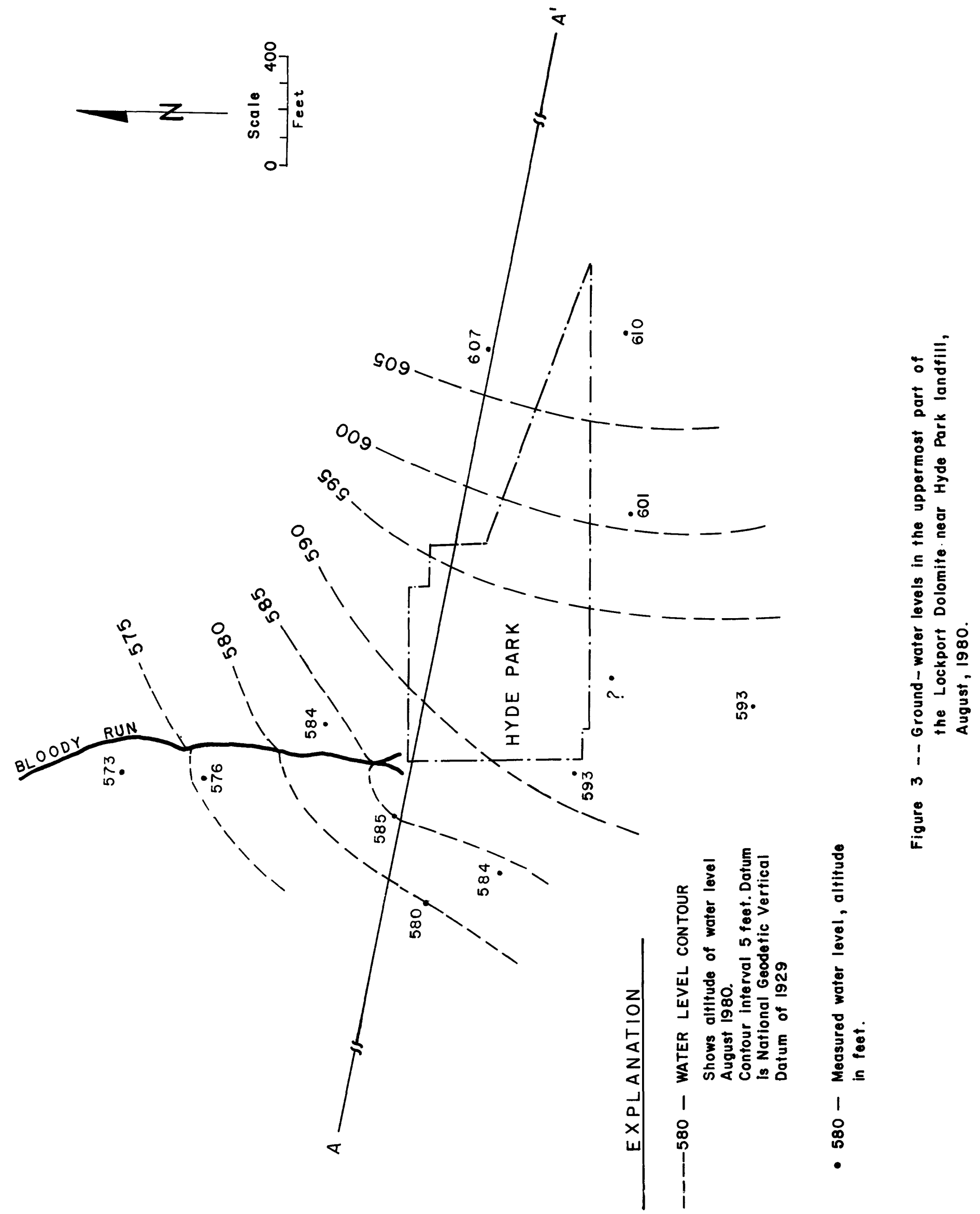




$$
\frac{\partial}{\partial x}\left(K_{r} K_{x x} \frac{\partial h}{\partial x}\right)+\frac{\partial}{\partial z}\left(K_{r} K_{z z} \frac{\partial h}{\partial z}\right)=0
$$

where:

$$
\begin{aligned}
\mathrm{h}= & \text { total hydraulic head (elevation head plus pressure head) in } \\
& \text { units of length; } \\
\mathrm{K}_{\mathrm{xx}}, \mathrm{K}_{\mathrm{zz}}= & \begin{array}{l}
\text { principal components of the hydraulic conductivity tensor at } \\
\text { saturation in units of length per time; }
\end{array} \\
\mathrm{K}_{\mathrm{r}}= & \text { relative hydraulic conductivity }\left(0<\mathrm{K}_{\mathrm{r}} \leq 1\right) .
\end{aligned}
$$

For the purposes of this simulation, hysteresis effects of the soll properties were assumed to be negligible and therefore ignored. Thus, $\mathrm{K}_{\mathrm{r}}$ was defined as a single valued function of pressure head using Gardner's equation (Gardner, 1958). Using this definition, $K_{r}$ is allowed to vary depending on the value of the unsaturated pressure head. This dependence of $K_{r}$ on the pressure head accounts for the nonlinearity of equation (1).

At this point, equation (1) is discretized by the Galerkin method; a special case of discretization techniques known as weighted residual methods. Using six nodal triangular elements (described in detail by Zienklewicz, 1977 ) as the approximating basis functions, the weighted integral residual of equation ( 1 ) over an elemental area can be described by:

$I^{e}(h)=\iint_{A} e^{N_{j}}\left\{\left[\frac{\partial}{\partial x}\left(K_{r} K_{x x} \frac{\partial}{\partial x}\right)+\frac{\partial}{\partial z}\left(K_{r} K_{z z} \frac{\partial}{\partial z}\right)\right] N_{i} h_{i}\right\} d A^{e}=0 ; i, j=1,2, \ldots, 6$

where:

$\mathrm{N}_{\mathrm{i}}, \mathrm{N}_{\mathrm{j}}=$ the chosen basis function for a six nodal triangular element;

$h_{1}=$ the unknown nodal values of hydraulic head which will be solved for;

$\mathrm{A}^{\mathrm{e}}=$ elemental area.

Assuming material properties $\mathrm{K}_{\mathrm{xx}}, \mathrm{K}_{\mathrm{zz}}$, and $\mathrm{K}_{\mathrm{r}}$ to be averaged over an elemental area, and using Green's first identity to eliminate the second derivatives in equation (2), a set of nonlinear ordinary differential equations is obtained for each element. Implementing a finite element assembly process yields a system of banded equations for the entire finite element region which takes on the form:

$$
\text { [S }\{h\}=\{F\}
$$

in which the matrix [S] contains the geologic properties and geometry of the elements, $\{h\}$ is a vector, which when solved for, will contain the values of total hydraulic head, and $\{F\}$ is the vector which contains the appropriate boundary conditions of the problem. This process has been successfully implemented in steady-state and transient analyses of porous media field 
problems and is described in detail by Maslia (1980) and Maslia and Aral (1982).

The finite-element analysis described here is a simulation of steadystate ground-water flow beneath the Hyde Park landfill. The finite element idealization of section $A-A^{\prime}$ is shown in figure 4. The idealized section is composed of 667 elements and 1,508 nodes. Two types of boundary conditions were used in the simulation of the idealized section: a constant total hydraulic head and a constant flux.

Referring to figure 4, boundaries $\overline{D E}$ and $\overline{F G}$ were assigned a constant flux value which is the estimated annual ground-water recharge ( $5 \mathrm{in} / \mathrm{yr}$ ). The landfill is reportedly covered by an impervious clay cap and therefore, the boundary $\overline{E F}$ was assigned a recharge value of zero. A zero flux value was also assigned to boundaries $\overline{\mathrm{CD}}, \overline{\mathrm{KB}}$, and $\overline{\mathrm{GH}}$.

Nodes on the boundaries $\overline{\mathrm{IJ}}$ and $\overline{\mathrm{JK}}$ were initially assigned constant head values of 555 feet above MSL--the reported elevation of hydraulic head in the buried conduits of the Niagara Power Project. However, boundary $\overrightarrow{\mathrm{JK}}$ was later modified based on a sensitivity analyses discussed below.

Boundaries $\overline{\mathrm{BC}}$ and $\overline{\mathrm{HI}}$ were assumed to represent seepage face conditions. Precise boundary values were initlally unknown. However, these values were determined by the digital model during the simulation and consequently applied to the boundaries. A detailed discussion of seepage face theory and its application in saturated-unsaturated finite element flow models may be found in Neuman (1973) and Maslia (1980).

A sensitivity analysis was conducted on boundary $\overline{\mathrm{JK}}$ to test the validity of the initial assumption of a constant head of 555 feet along this boundary. The analysis involved removing the constant head values inftially assigned to nodes on boundary $\overline{\mathrm{JK}}$ and replacing them with constant flux values of varying magnitudes. The process of obtaining the final fluxes required two steps: (1) applying the flux values determined during the simulation with the initial constant head of 555 feet to determine effects on boundary $\overline{\mathrm{JK}}$; (2) applying increasing values of flux until an acceptable head distribution in the Rochester near the conduits is reached. Step 1 resulted in no difference in head distribution on or near $\overline{\mathrm{JK}}$. Step 2 resulted in a more realistic head distribution from a hydrogeologic standpoint in the Rochester Shale. Neither step 1 nor 2 caused any change in the head distribution in the area of greatest interest between Bloody Run and the Niagara Gorge.

In summary, boundary conditions along the conduits $(\overline{\mathrm{GH}}, \overline{\mathrm{HI}}, \overline{\mathrm{IJ}}$, and $\overline{\mathrm{JK}}$ ) were specified as follows: (1) $\overline{\mathrm{GH}}$ as zero flux, (2) $\overline{\mathrm{HI}}$ as a seepage face, (3) $\overline{I J}$ as a constant head of 555 feet (MSL)--(this is the interval with drains directly to the conduits), and (4) $\overline{\mathrm{JK}}$ as constant flux.

\section{Input of Hydrologic Parameters}

Four hydrogeologic units were represented in the idealized section for simulation purposes ( $f$ ig. 4). The four units are: (1) glacial till; 
(2) Lockport Dolomite (upper unit); (3) Lockport Dolomite (lower unit); and

(4) Rochester Shale. Table 2 lists the hydraulic parameters assigned to the four units during simulation including initial and final values and the range of values used during calibration.

The horizontal hydraulic conductivity value assigned to the glacial till for the purposes of the simulation was $0.0283 \mathrm{ft} / \mathrm{d}(0.864 \mathrm{~cm} / \mathrm{d})$. This is an average value determined from field tests (table 1) and was not changed during calibration.

Initially the upper unit of the Lockport was assigned a saturated horizontal hydraulic conductivity of $6.6 \mathrm{ft} / \mathrm{d}$. During calibration, the conductivity was varied slightly and final values ranged from $4.9 \mathrm{ft} / \mathrm{d}$ $(150 \mathrm{~cm} / \mathrm{d})$ in the zone east of Bloody Run to $6.6 \mathrm{ft} / \mathrm{d}(200 \mathrm{~cm} / \mathrm{d})$ in the zone west of Bloody Run.

The lower untt of the Lockport Dolomite in the Idealized section was initially assigned a horizontal saturated hydraulic conductivity value of $2.0 \mathrm{ft} / \mathrm{d}(60 \mathrm{~cm} / \mathrm{d})$. Slight changes were made during calibration as shown in table 2 .

In previous discussion, it was noted that the horizontal hydraulic conductivity $\left(\mathrm{K}_{\mathrm{xx}}\right)$ greatly exceeds the vertical conductivity $\left(\mathrm{K}_{\mathrm{zz}}\right)$. The ratio of $\mathrm{K}_{\mathrm{xx}}: \mathrm{K}_{\mathrm{zz}}$ cannot be quantified from field data but was initially estimated to be 5:1 in the upper unit of the Lockport and 10:1 in the lower unit of the Lockport. As shown in table 2, calibration indicated that much higher values are more valid.

The Rochester Shale was assumed to have very low permeability due to its insignificantly low yield of water to wells (table 1). A value for the horizontal saturated hydraulic conductivity of $0.02 \mathrm{ft} / \mathrm{d}(0.6096 \mathrm{~cm} / \mathrm{d})$ was assigned initially and was not varied during calibration.

Vertical jointing is prominent in rocks exposed along the Niagara River Gorge (Johnston, 1964). Therefore, in the present analysis, the authors assumed that the vertical conductivity exceeds the horizontal conductivity near the river. Therefore we assigned ratios of horizontal to vertical conductivity $\left(\mathrm{K}_{\mathrm{xx}}: \mathrm{K}_{\mathrm{zz}}\right)$ of $1: 10$ in both units of the Lockport Dolomite and in the Rochester Shale for the first 200 feet of cross-sectional distance from the Niagara River Gorge.

\section{Mode1 Calibration Procedure}

The objective of the model callbration was to simulate the position of the estimated steady-state water table and the vertical distribution of hydraulic head (Iines of equipotential in $\mathrm{fig} .2$ ) within the four hydrogeologic layers. The calibration evolved into a three-step process:

1. After first determining the overall sensitivity of the model to various input parameters such as recharge and hydraulic conductivity the recharge rate (constant flux boundary condition on boundaries $\overline{\mathrm{DE}}$ and $\overline{\mathrm{FG}}$ ) was 
Table 2.--Hydrologic parameters used in Hyde Park simulation (section A-A').

\begin{tabular}{|c|c|c|c|c|}
\hline & & $\begin{array}{l}\text { Initial } \\
\text { values }\end{array}$ & $\begin{array}{l}\text { Range of } \\
\text { values during } \\
\text { calibration }\end{array}$ & $\begin{array}{l}\text { Final } \\
\text { values }\end{array}$ \\
\hline Recharge ( & ches per year) & 2.2 & $2.2-6.1$ & 5.0 \\
\hline & $\begin{array}{l}\text { Saturated hydraulic } \\
\text { conductivity }\left(\mathrm{K}_{\mathrm{xx}}\right) \\
\mathrm{ft} / \mathrm{d}(\mathrm{cm} / \mathrm{d})\end{array}$ & 0.028 & No change & $0.028(0.864)$ \\
\hline & $\begin{array}{l}\text { Ratio of anisotropy } \\
\qquad \frac{\mathrm{K}_{\mathrm{Xx}}}{\mathrm{K}_{\mathrm{Zz}}}\end{array}$ & $1: 1$ & $1: 1-10: 1$ & $2.5: 1$ \\
\hline Upper unit & $\begin{array}{l}\text { Saturated hydraulic } \\
\text { conductivity }\left(\mathrm{K}_{\mathrm{xx}}\right) \\
\mathrm{ft} / \mathrm{d}(\mathrm{cm} / \mathrm{d})\end{array}$ & 6.6 & $4.9-6.6$ & $\begin{array}{c}4.9-6.6 \\
(150-200)\end{array}$ \\
\hline Dolomite & $\begin{array}{l}\text { Ratio of anisotropy } \\
\qquad \frac{\mathrm{K}_{\mathrm{Xx}}}{\mathrm{K}_{\mathrm{zz}}}\end{array}$ & $5: 1$ & $5: 1-100: 1$ & $100: 1$ \\
\hline Lower unit & $\begin{array}{l}\text { Saturated hydraulic } \\
\text { conductivity }\left(\mathrm{K}_{\mathrm{xx}}\right) \\
\mathrm{ft} / \mathrm{d}(\mathrm{cm} / \mathrm{d})\end{array}$ & 2.0 & $1.5-2.0$ & $\begin{array}{l}1.5-2.0 \\
(45-60)\end{array}$ \\
\hline Dolomite & $\begin{array}{l}\text { Ratio of anisotropy } \\
\frac{\mathrm{K}_{\mathrm{xx}}}{\mathrm{K}_{\mathrm{zz}}}\end{array}$ & $10: 1$ & $10: 1-1000: 1$ & $1000: 1$ \\
\hline & $\begin{array}{l}\text { Saturated hydraulic } \\
\text { conductivity }\left(\mathrm{K}_{\mathrm{xx}}\right) \\
\mathrm{ft} / \mathrm{d}(\mathrm{cm} / \mathrm{d})\end{array}$ & 0.02 & No change & $0.02(0.61)$ \\
\hline & $\begin{array}{l}\text { Ratio of anisotropy } \\
\qquad \frac{K_{x x}}{K_{z z}}\end{array}$ & $25: 1$ & $25: 1-1000: 1$ & $1000: 1$ \\
\hline
\end{tabular}

1/ For the first 200 feet in the cross-sectional distance from the Niagara River Gorge:

$$
\frac{\mathrm{K}_{\mathrm{xx}}}{\mathrm{K}_{\mathrm{zz}}}=1: 10
$$


fixed at $5 \mathrm{in} / \mathrm{yr}$. This is the most probable rate determined by reviewing work done by LaSala (1967).

2. Next the saturated horizontal conductivity values $\left(\mathrm{K}_{\mathrm{xx}}\right)$ were varied within acceptable limits of the field data such that the simulated position of the water table matched reasonably well the position based on field data.

3. The final step in the calibration process was to approximate the total hydraulic head distribution by varying the ratio of horizontal to vertical saturated hydraulic conductivity values in the four geologic units. The simulated heads after calibration generally matched the field values within 5 feet in the upper unit of the Lockport Dolomite and glacial till.

No attempt was made to precisely define the head distribution during calibration due to the lack of hydraulic head data within the modeled section (fig. 2). Furthermore, from Investigations by Johnston (1962, 1964), the Lockport Dolomite is known to be characterized by high permeability along bedding joints and low permeability in unjointed rock. This leads to a very complex head distribution. In order to precisely simulate such a distribution, much more detailed field data would be required and a more refined idealization of section $A-A^{\prime}$ would need to be simulated.

\section{SUMMARY OF GROUND-WATER FLOW BASED ON SIMULATION}

The simulated position of the water table and distribution of heads under steady-state conditions along section $A^{-} A^{\prime}$ is shown in figure 5 . In that part of the section (near the landfili) where fleld measurements are available, the simulated head distribution (fig. 5) compares favorably with the field data (f1g. 2). Generally there is less than 5 feet difference between simulated and field head values. Elsewhere in the section where no field water-level data exist, the simulation is considered to be valid because similar values for hydraulic conductivities were applied for each unit. Due to the absence of any field data for the Rochester Shale, the accuracy of simulated heads in this unit is unknown.

Figure 5 shows that the water table is near land surface west of the landfill towards the gorge. To the east, however, the water table is lower and occurs in the upper part of the dolomite. Note that the inferred watertable divide is skewed to the west with increasing depth.

The simulated heads in figure 5 indicate higher velocities in the Lockport Dolomite than in the overlying glacial till and the underlying shale. The model was used to calculate the velocity distribution from the simulated heads and to determine more precisely the location of the water-table divide. Figure 6 shows Darcy velocity vectors for selected elements (note: the Darcy velocities are plotted at the centroid of each element in section A-A'). The length of the arrows is scaled in accordance with the relative magnitude of each velocity. It should be emphasized that the velocity values are average; a more detailed analysis is needed to obtain precise point velocity values. 
Application of the Darcy equation to the calculated velocities (fig. 6) indicates that approximately 80 percent of the seepage along the gorge face is from the Lockport Dolomite.

The estimated times of travel of ground water from the landfill to the gorge along three flow paths are shown in figure 7. These times were calculated with the Darcy equation using the velocities shown in figure 6 and estimated effective porosities. Porosities used for this calculation are: 0.25 for glacial till, 0.02 for the upper unit of the Lockport, and 0.01 for the lower unit of the Lockport. Travel times range from 5.8 years in the upper unit of the Lockport Dolomite to 490 years in the glacial t111. Note that these values were calculated using a starting point midway between the top of the landfill and the top of the Lockport Dolomite. Movement would be much more rapid in the last 400 feet before reaching the gorge compared to movement elsewhere in the three formations. It should be emphasized that the travel times stated are for ground water and represent the maximum possible rate for transport of chemicals. In general, chemicals can be expected to move at slower rates.

Based on simulation, ground-water, flow near the Hyde Park landfill can be summarized as follows:

1. Highest Darcy velocities occur in the upper 15 feet of the Lockport Dolomite and locally in part of the lower unit of the Lockport. Darcy velocities range from 0.01 to $0.1 \mathrm{ft} / \mathrm{d}$ in most of the upper unt the Lockport; real velocities range from about 1.5 to $4.8 \mathrm{ft} / \mathrm{d}$ (except near the Niagara Gorge).

2. Lowest Darcy velocities (less than $0.00001 \mathrm{ft} / \mathrm{d}$ ) occur in the Rochester Shale.

3. Moderately low velocities occur in the glaclal t111 where saturated to the west of the landfill. Darcy velocities range from 0.001 to 0.01 $\mathrm{ft} / \mathrm{d}$ and real velocities average $0.018 \mathrm{ft} / \mathrm{d}$.

4. The simulated location of the ground-water divide shown in figure 5 indicates that all ground water entering near Hyde Park landfill and flowing beneath the landfill will discharge at the gorge.

5. The zone of highest velocities (and presumably greatest potential for transporting chemical contaminants) is in the upper unit of the Lockport from Bloody Run to the gorge and in the lower unit of the Lockport from the western limit of the landfill to the gorge. The time required for ground water to move from the vicinity of the landfill to the gorge in the Lockport is about 5 to 7 years. 


\section{REFERENCES}

Elder, V. A., Proctor, B. L., and Hites, R. A., 1981, Organic compounds found near dump sites in Niagara Falls, New York: Environmental Science and Technology, v. 15, no. 10, p. 1237-1242.

Gardner, W. R., 1958, Some steady-state solutions of the unsaturated moisture flow equation with application to evaporation from a water table: Soil Sclence, v. 85, pp. 228-232.

Interagency Task Force on Hazardous Wastes, 1979, Hazardous waste disposal in Erie and Niagara Counties, New York: New York Department of Environmental Conservation, 325 p.

Johnston, R. H., 1962, Water-bearing characteristics of the Lockport Dolomite near Niagara Falls, New York: U.S. Geological Survey Professional Paper 450-C, p. C123-C125.

1964, Ground water in the Niagara Falls area, New York: New York Water Resources Commission Bulletin GW-53, 93 p.

LaSala, A. M., 1967, New approaches to water-resources investigations in upstate New York: Ground Water, v. 5, no. 4, p. 6-11.

Maslia, M. L., 1980, Numerical modeling of saturated-unsaturated fluid flow through porous media: Unpublished Master's Thesis, Georgia Institute of Technology, 132 pages.

Maslia, M. L., and Aral, M. M., 1982, Evaluation of a chimney drain design in an earthfill dam: Ground Water, v. 20, no. 1, p. 22-31.

Neuman, S. P., 1973, Saturated-unsaturated seepage by finite elements: Journal of the Hydraulics Division, American Society of Civil Engineers, HY12, p. 2233-2250.

U.S. District Court, Buffalo, New York, 1981, Reply brief of the United States of America; testimony of L. Miller, R. H. Johnston, K. Davis, and D. B. Twede11: Civil action no. 79-989, v. II.

Zlenkiewicz, O. C., 1977, The finite element method: McGraw-Hi11 Publishing Company, Limited, London, 774 p. 


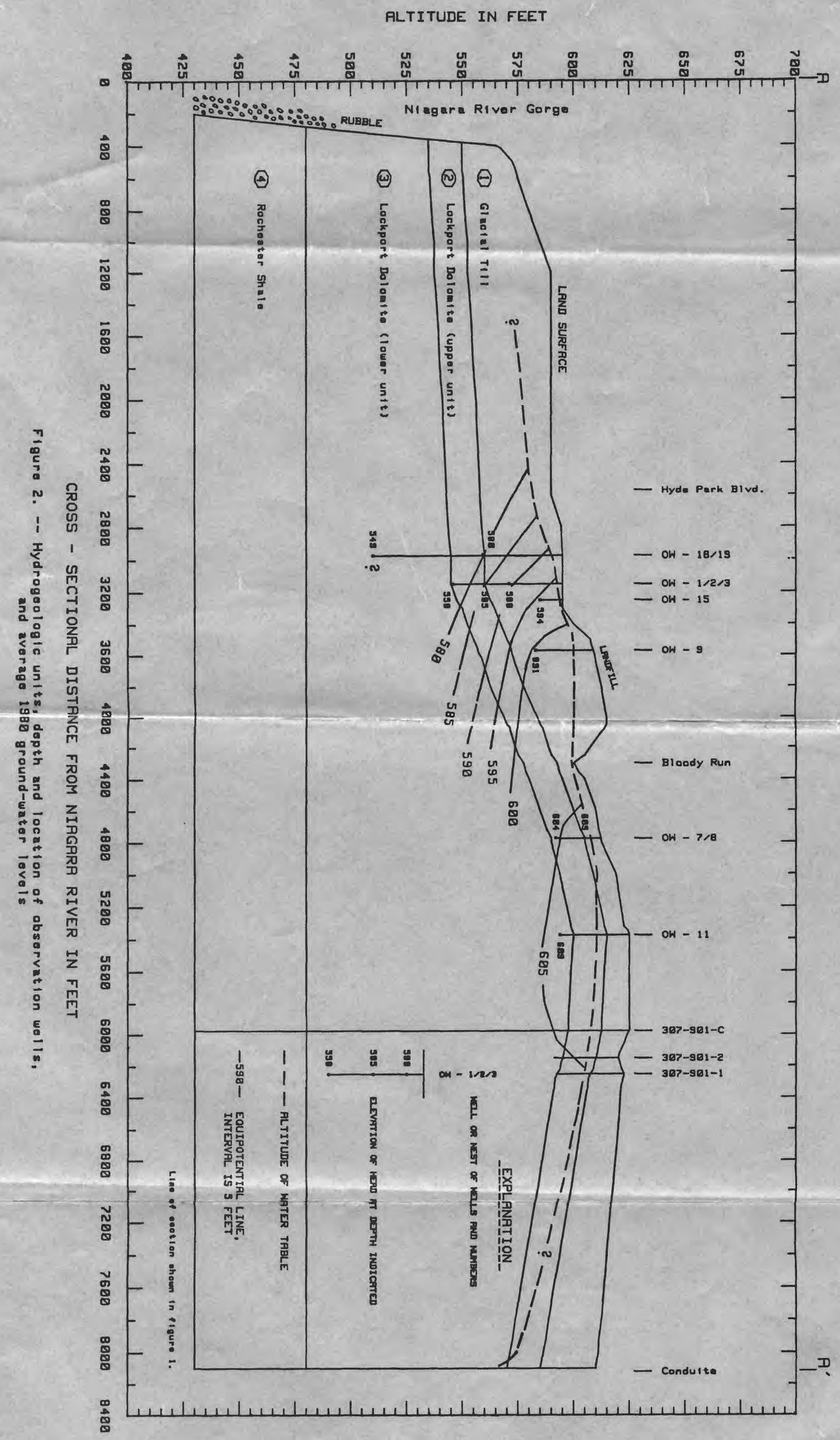


RLTITUDE IN FEET

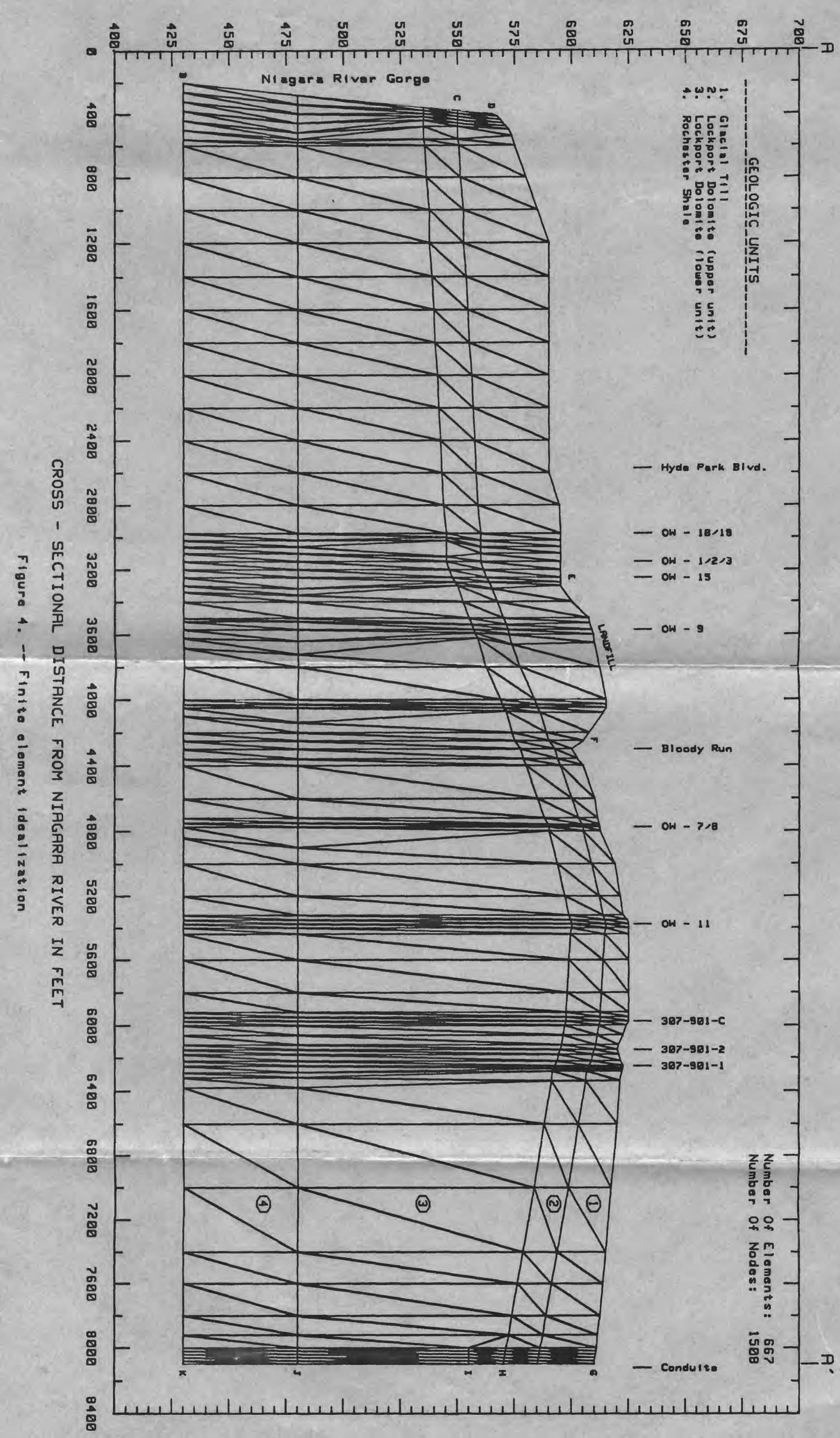




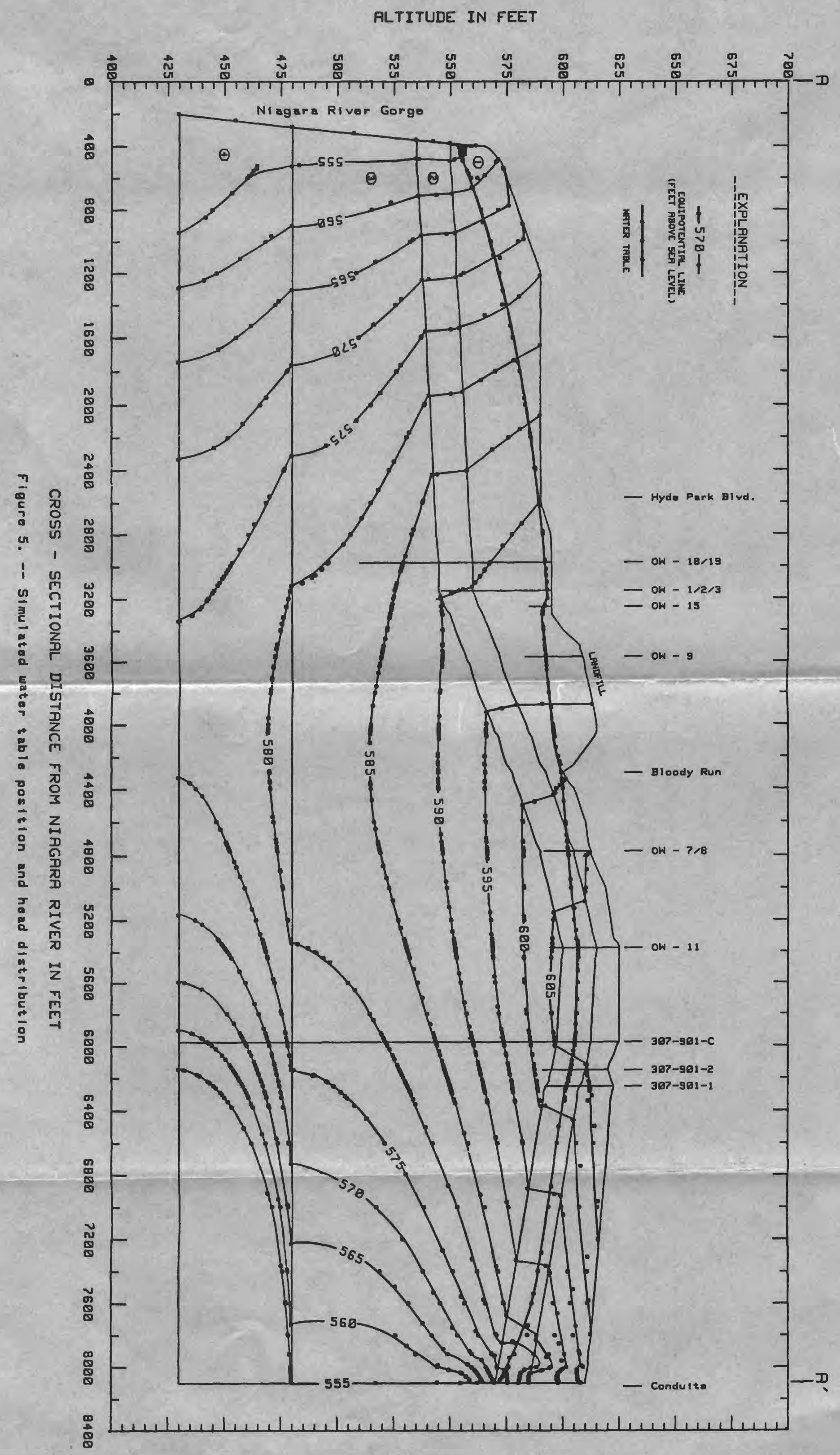




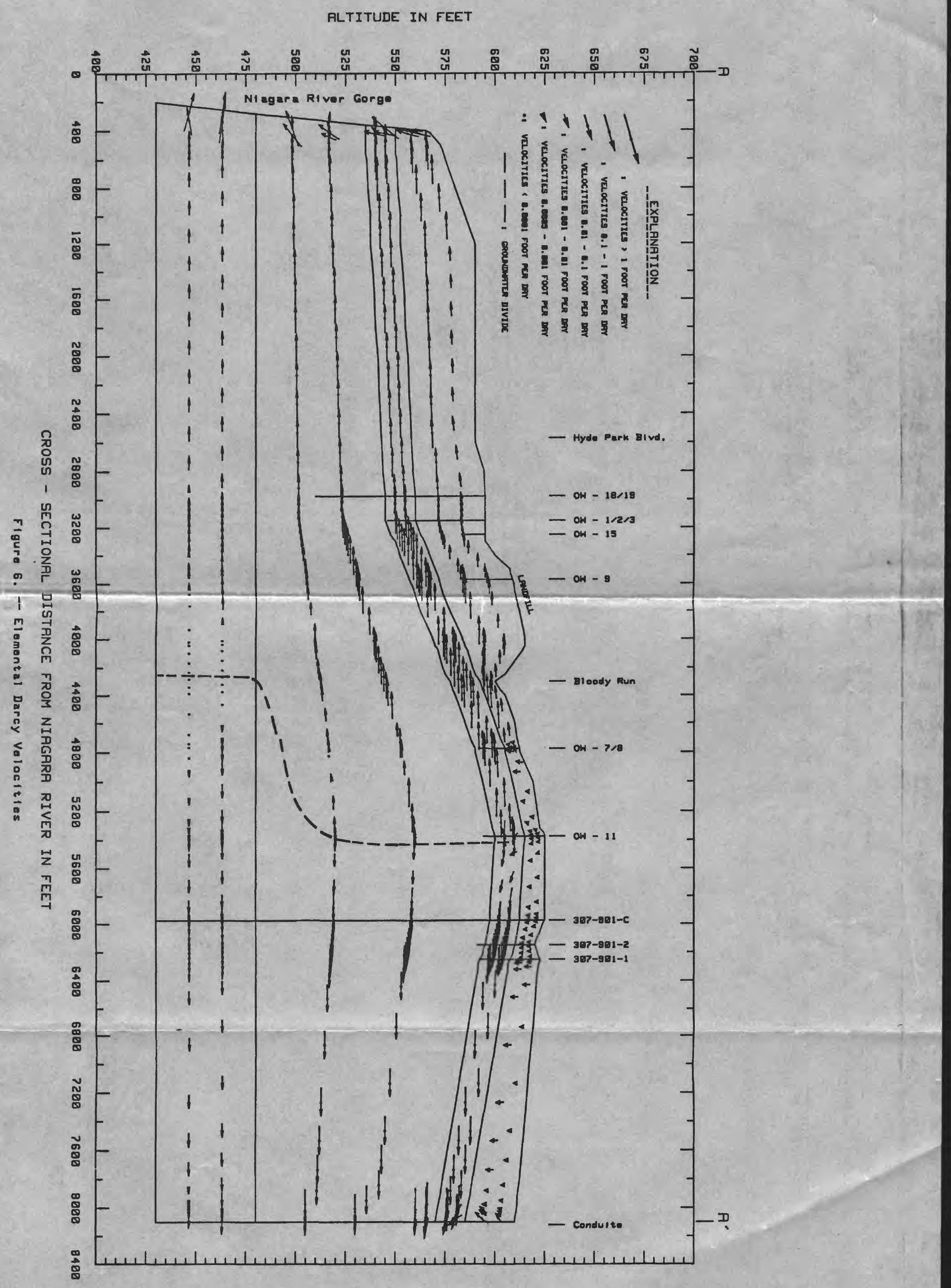




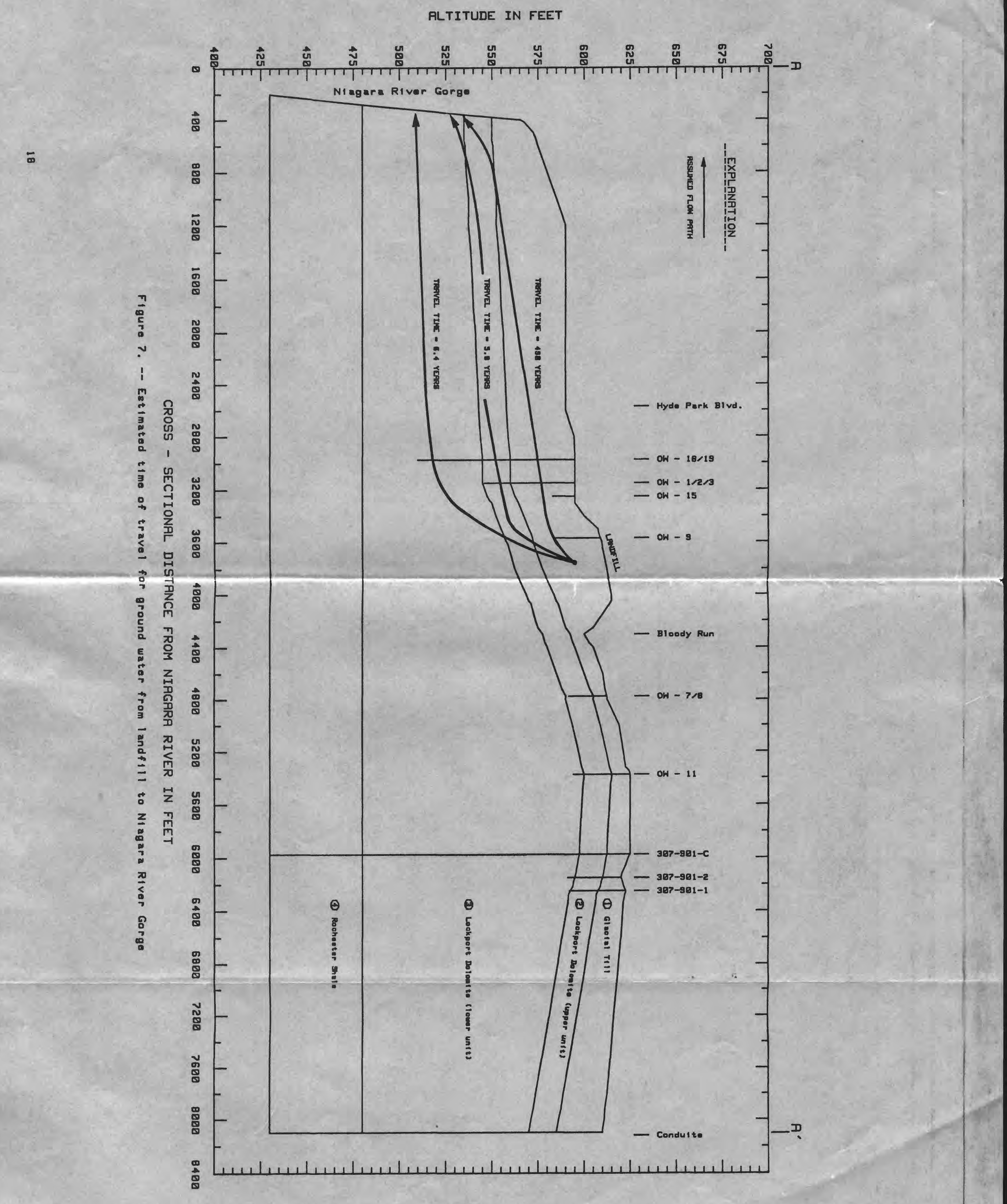

